\title{
Study on Influencing Factors of Value Improving for Enterprise Groups' Finance Shared Service Central
}

\author{
Yin Yang ${ }^{1, a}$, Wenyi $\mathrm{Li}^{1, \mathrm{~b}^{*}}$, Ruoxi Feng ${ }^{1, \mathrm{c}}$ and Xiaoxiao $\mathrm{Xu}^{1, \mathrm{~d}}$ \\ ${ }^{1}$ School of Accounting, Wuhan Textile University, Wuhan, China \\ acs_yangyin@hust.edu.cn, ${ }^{b}$ ucfsingh@hotmail.com, ${ }^{c}$ ruoxipaper@gmail.com, \\ 'Xylona1228@outlook.com
}

\begin{abstract}
Keywords: Finance Shared Service Center; Process Reengineering; Influencing Factors; Value Improving
\end{abstract}

\begin{abstract}
Based on two business processing reengineering theories that are the enterprise group's core and subservience, this paper discusses the finance shared service center's establishment process on the basis of enterprise group's financial management and control revolution and business processing reconstruction. It also pulls the influencing factors that enterprise group carries out financial shared services core value together, and analyzes from dimensions such as technology, personnel, strategy, organization, service, management and process etc. The following statements present its important value. It covers the shortage that there are too many studies on financial shared services core value's influencing factors but restricted to subservience processing reconstruction to perfect the influencing factors of financial shared services core value's lifting. What's more, it provides support to bring the effect of financial shared services core value and superior function for enterprise group.
\end{abstract}

\section{Introduction}

Shared services were founded in 1980s by Ford Motor Company at the earliest. At the evening of 1980s, DuPont Company and General Electric Company established the shared services center in succession [1]. In 1990s, American large transnational corporations put group financial shared services into practice one after another, such as Ford, General, DuPont, HP, etc. At that time, financial shared services mainly applied to finance and accounting to provide related content of financial accounting and financial analysis for groups, with the purpose of strengthening enterprise groups' entire control. With the development of globalization, market competition is increasingly fierce. Enterprise groups' financial shared services changes from cost center to profit center gradually. Through signing service agreements with enterprise groups, service contents can be confirmed, fees can be charged based on the services complexity and workload. Thus, its own working characteristics can realize the transformation [2]. A part of the current management functions of finance shared service center are gathered to a cooperation strategy which is new semi-independent business unit. This business unit is equipped with special management organizations. It is aimed at raising efficiency, creating the value, saving the cost and improves the services quality of internal customers [3].

The reform and opening-up policy makes our national enterprise groups spring up at a fast speed. Being scaled and globalization make the importance of our national enterprise groups operation and management prominent constantly. Also, the weaken problems of financial management is rising gradually. For example, the costs are increasing, financial risks is becoming larger, the difficulty of management and control is increasing to move forward a single step, the benefit relating to all parties are challenged, services quality is hard to enhance, and the financial working is inefficient. All of these problems restrict our national enterprise groups' sustained, healthy and rapid development seriously. Besides, they have caused a strong reaction from both of theoretical and practical cycles. Financial management and control ability's improvement and financial management revolution which are relating to enterprise group have become the rush problem that are desperately resolved by enterprise 
groups. How to apply financial shared services and processing reconstruction, how to grasp two business processing reconstructions' influencing factors what is about enterprise groups' core and subservience to build finance shared service center and solve the financial management problems that are met during the development of enterprise groups, assuring enterprise groups' benign development. These arguments have become hot spots that are concerned by both of financial management theorists and enterprise groups' business managers.

Finance shared service center is the product produced by enterprise groups through carrying on finance transition and the revolution of organizational innovation. At the same time, it is a creative breakthrough of business processing reconstruction that is carried on by enterprise groups. However, what remains to be further in-depth is the studies with regard to what and how to pay attention to influencing factors, in order to promote financial shared services central value. Enterprise groups have taken the researches on subservient business processing' influencing factors of financial shared services models. But it doesn't introduce the influences of management and control that are brought by enterprise groups' core business processing reconstructions. However, both of enterprise groups' core and subservience business processing can promote enterprise groups' financial shared services central value positively. Therefore, the article is aimed at filling up this vacancy. On the basis of enriching and perfecting the research and analysis which is relating to the weakening problems of Chinese enterprise groups' financial management that are brought by finance shared service center and processing reconstruction theories, it applies enterprise groups' two business processing reconstruction of core and subservience as a basis. It draws a conclusion on improving influencing factors of enterprise groups' financial shared services central value. The article reveals the relationships between these influencing factors deeply. Besides, it provides strong supports and theory references for enterprise groups to build up the finance shared service center.

\section{Research and Analysis of Influencing Factors}

Combined with the theoretical research of finance shared service center's development, researchers collect and systemize a lot of relating research results, summarize, refine, conclude and confirm the influencing factors and their connotations that can enhance the financial shared services central value, on the basis of processing reconstruction of core and subservience, taking processes that are built during the construction of finance shared service center over the years by enterprise groups as research objects.

The effect of technology factor on financial shared service central value. The development of shared services concept cannot do without the innovation of modern information technology. During the process of combination between the information produced in the developing worldwide process of enterprise groups, modern information technology plays an important role. The development of financial shared services center also needs the support from information technology. Information technology is applied and instilled. On the one hand, it can improve enterprise groups' progress on production technology and production efficiency. On the other hand, it can enhance the innovative revolution and optimization of financial organization and processing [4]. The constant development and innovation of information technology provide technical support for financial management's synergy and share. It must cause an innovative revolution of enterprise groups' financial management information. Thus, the development of finance shared service center will be promoted further [5].

Information technology provides powerful information sharing platform system for finance shared service center. It fixes all kinds of administrative system and financial management process method under the circumstance of the consolidated database. Enterprise groups' different core and subservient business processing have been defined in the information technology, in order to assure the project and development of enterprise groups' overall strategy. At the core of accounting module, decision-making support module, online reimbursement module, budget management module, image management 
module and bank-enterprise inter-link module and so on, financial shared services information platform combining with the technology of database, IT and management information system establishes a technical foundation for enterprise groups to carry on finance shared service center and improve financial shared services central value further.

The effect of personnel factor on financial shared service central value. After the implement of finance shared service center, it not only needs background technological development and maintenance staff, but also does it need new high-end financial and accounting personnel who can use finance shared service center's all kinds of applications. The basic works of financial shared center qualifies by the traditional hand-made accountants who are trained specially. The key of presenting finance shared service center's value if financial decision-making and analysis. These works will be finished by senior financial and accounting personnel. Therefore, under the environment of financial shared services' rapid development, the society has to cultivate more senior financial staff, expand and update financial workers' knowledge structure. Also, they should accept the education of financial analysis and decision-making to catch up with the development of information technology. At the same time, due to the reason that the whole financial framework is regrouped at the center of finance shared service center and consolidated standards are confirmed, it is critical to conduct all-staff pre-service training and improve the learning ability constantly to meet positions' demands.

On the one hand, good personnel management in the finance shared service center needs that corporation groups earnestly analyze the features of the personnel of the finance shared service center. They should also apply differentiated management to inferior and superior financial and accounting personnel with aims which can mobilize the enthusiasm of the operation and the initiative of people. On the other hand, groups emphasize on the trainings aimed at IT, financial knowledge and performance process in the finance shared service center is instrumental for employees to understand the finance shared service center deeply resulting in their proficiency in utilizing the new technique and enhancing the value of the finance shared service center further.

The effect of strategy factor on financial shared service central value. During the implementation of finance shared service center, corporation groups consistently analyze and evaluate strategic factors and ensure that the quality of service is correspondent to what customers require. Rzmirez thinks that there is a direct link between the target location of the finance shared service center and the strategic development and plans of the groups [7]. To save management costs, groups hope to improve the costs of the services' operation as a whole through implementing finance shared service center and consequently, creating values. Carrying out differentiation strategies, groups wish to create unique points of their own among rivals in the same industry through implementing finance shared service center and further form their own competitive strengths. Putting international strategies into practice, groups want to meet the need of internationalization through the center and tackle complicated problems of over input of personnel, high additional costs of mergers and the hardship of standardization management. Therefore, researchers can set a development goal for the implementation of finance shared service center and further increase the value of it by means of strategic factors like planning, implementation, locating, setting targets, choosing places and so forth.

The effect of organization factor on financial shared service central value. The structure design of organizations is a critical element of organization factor, through which researchers can clarify the relationships between finance sharing service and other components of groups' structures and rights and obligations for individual unit within the finance shared service center. It enables groups to avoid obstacles in operations caused by unclear separation of rights and obligations which make organizations operate efficiently and promise the achievement of organizations' targets [8]. The finance shared service center is a typical centralized organization center. It redefines the business interface and business relationship between groups' headquarters and respective operating departments and branches. Organizations of groups separate basic work like daily receipts, financial reimbursements, verification, financial accounting and preparation of statements in branches and in all 
operating departments and tackle those collectively in the finance shared service center. Meanwhile, corresponding accounting and financial positions will be canceled in operating departments and branches in order to realize centralization of financial personnel. Actually, the implementation of the finance shared service center is a revolution to the finance management center. Apart from that, what organizational management contributes to the value of finance sharing service is that it can help corporation groups to effectively response to reform and further enhance its value.

The effect of service factor on financial shared service central value. Under the environment of finance shared service center, the feature of service is the objective that groups need to supply ultimately [9]. Finance sharing service who aims at providing high cost-benefit ratio has a feature of service. It is oriented in customers' needs, with the purpose to enhance customers' satisfaction and set relevant benchmarks, and provides services to external and internal customers of the group and receives service fees according to the service agreements prior to all work. Besides, finance sharing service has a feature of contracts. It clarifies its duties and work range in accord with service agreements and it defines the factual relationships between sharing service center and its customers, contents of services, time limitation and quality standard through signing the service level agreement.

The group's headquarter signs the group's internal service level agreement with its branches that accept the services and its operating units. It will clarify the rights and obligations between the finance shared service center and its operating branches and the methods to solve their communication problems, therefore, eventually, supply better services relied on finance shared service center. The internal service level agreement made by the group is a service standard which takes two parties interests into consideration and it comes from the negotiation between the finance shared service center and the branches that accept the services.

The effect of management factor on financial shared service central value. Contemporary enterprise group management system is a new type of system whose conditions are clear duties, clarified ownership, separation of government and corporation and scientific management based on the legal person system for developed groups [10]. Its main form is company and assurance is the limited responsibility system. However, some underway groups hold several misunderstandings about contemporary enterprise management system, such as legal person system, partnership responsibility system and so forth which may lead to faulty notion on the action taken of the finance shared service center. What's more, most enterprises operate under centralization of power and the basis of establishing independent legal person's finance service center is not so firm. In addition, the company level lacks a set of reform system relating to personnel separation and function separation corresponding to the restructure of financial operation which may become the barrier to implement of future finance shared service center. Researchers can combine management factors such as management system, financial management system, senior management support, internal control, risk management and performance management to provide groups with secured platform to take finance shared service center into action and further directly promote the value of finance shared service center.

The effect of process factor on financial shared service central value. BPR was a popular management concept and method in 1980s. According to the Hammer's authoritative definition in the magazine Reengineering of Corporations, BPR gives fundamental rethinks and thorough re-devise to groups' business process in order to remarkably enhance the contemporary key performance indexes like costs, quality, service and speed. Substantively, the process of setting up finance shared service center is that of finance process reengineering. The implementation process of the groups finance shared service center should obey six principles: the separation of basic operation and financial analysis, making the financial data more relevant to operations, whole-stage sharing of data, integrated financial information system, standard financial procedures and costs, quality, efficiency and satisfaction. Researchers have achieved to transfer financial management from a matter of process to performance through process reengineering. The process reengineering cannot be utterly solved at once which can only truly bring us the value of process reengineering through process management and 
continuous improvement and modification to the process and performance after reengineering. As a result, researchers should provide groups action on finance shared service center with design on performance rules combined with process factors like process management, definition of process sand standard of process.

\section{Summary}

Based on the reengineering theory about the core and assisted performance's process, this paper studies the establishing process of finance shared service center based on groups' reform of financial management and the performance process. Furthermore, it summarizes and confirms the influential essentials that increase the value of the groups' finance shared service center and extracts the influence factors such as t technology, personnel, strategy, organization, service, management and process with analysis and clarifies their inter-relationships. The paper's contributions includes following parts. First, the research conclusions make up for the lacking in studies based on influence factors that enhance the value of the core and assisted performance sharing service and put forward the key elements about groups' actions finance sharing service. Simultaneously, it enriches the research on the finance shared service center and its fruits reveal the factors that promote the value of finance shared service center from the groups and financial management levels to core and assisted performance process's analysis. Secondly, the conclusions offer the supports and guidance on how to formulate finance shared service center, how to make the best of finance shared service center's advantages and how to confirm the influencin factors to enhance its value and its implementation approaches.

\section{Acknowledgement}

This work was financially supported by the 2015 Humanities and Social Science Project of Education Department of Hubei Province (Study on business volume balance optimization in finance shared service center (15Q100)).

\section{References}

[1] R.W. Gunn, D.P. Carberry, R. Frigo, S. Behrens, Shared services: major companies are re-engineering their accounting functions, Management Accounting. 75(1993) 22-28.

[2] D. Keith, R. Hirschfield, The benefits of sharing, HR Focus. 73(1996) 15-16.

[3] Bergeron, Essentials of shared services, 1rd Edition, New York, NY: John Wiley\&Sons Inc., 2003, pp. 36-52.

[4] A. Kris, M. Fahy, Shared service centers, 2rd Edition, London: Pearson Education Limited, 2003, pp. 78-104.

[5] A. Jeston, K. John, What managers need to know about the management of business processes. 1rd Edition, New York, NY: Meghan-Kiffer Press, 2009, pp. 68-79.

[6] M. Fahy, The financial future, Financial Management. 21(2005) 210-219.

[7] J. Ramirez, Utilizing measurement to drive continuous improvement within FSSC, International Journal of Information Management. 9(2007) 16-28.

[8] R. Gill, Why cloud computing matters to finance, Strategic Finance. 7(2011) 43-48.

[9] W. Martin, Critical success factors of shared service projects-results of an empirical study. Advances in Management, 14(2011) 21-26.

[10] M. Derven, Advancing the Shared Services Journey Through Training. T+D, 4(2011) 58-64. 